\title{
Cooperating for service excellence in multi-channel service systems: an empirical assessment
}

Citation for published version (APA):

Wiertz, C., de Ruyter, J. C., \& Streukens, A. C. P. (2003). Cooperating for service excellence in multichannel service systems: an empirical assessment. METEOR, Maastricht University School of Business and Economics. METEOR Research Memorandum No. 016 https://doi.org/10.26481/umamet.2003016

Document status and date:

Published: 01/01/2003

DOI:

10.26481/umamet.2003016

Document Version:

Publisher's PDF, also known as Version of record

\section{Please check the document version of this publication:}

- A submitted manuscript is the version of the article upon submission and before peer-review. There can be important differences between the submitted version and the official published version of record.

People interested in the research are advised to contact the author for the final version of the publication, or visit the DOI to the publisher's website.

- The final author version and the galley proof are versions of the publication after peer review.

- The final published version features the final layout of the paper including the volume, issue and page numbers.

Link to publication

\footnotetext{
General rights rights.

- You may freely distribute the URL identifying the publication in the public portal. please follow below link for the End User Agreement:

www.umlib.nl/taverne-license

Take down policy

If you believe that this document breaches copyright please contact us at:

repository@maastrichtuniversity.nl

providing details and we will investigate your claim.
}

Copyright and moral rights for the publications made accessible in the public portal are retained by the authors and/or other copyright owners and it is a condition of accessing publications that users recognise and abide by the legal requirements associated with these

- Users may download and print one copy of any publication from the public portal for the purpose of private study or research.

- You may not further distribute the material or use it for any profit-making activity or commercial gain

If the publication is distributed under the terms of Article $25 \mathrm{fa}$ of the Dutch Copyright Act, indicated by the "Taverne" license above, 
COOPERATING FOR SERVICE EXCELLENCE IN MULTI-CHANNEL SERVICE SYSTEMS: AN EMPIRICAL ASSESSMENT

\author{
Caroline Wiertz ${ }^{1}$ \\ Maastricht University \\ Ko de Ruyter, Ph.D. \\ Maastricht University \\ Cherie Keen, Ph.D. \\ Fairfield University \\ Sandra Streukens \\ Maastricht University
}

${ }^{1}$ Contact Author. Ph.D. Candidate, Maastricht University, Faculty of Economics and Business Administration, Department of Marketing and Marketing Research,

PO Box 616, 6200 MD, Maastricht, The Netherlands. Phone: +31 433883716.

Email: c.wiertz@mw.unimaas.nl 


\begin{abstract}
In today's technological environment, rapid advances have considerably increased the number of service delivery options available to companies. Consequently, in addition to the traditional network of channel intermediaries, many firms have established Customer Interaction Centers (CICs) to optimize their pre- and post-sales service offering to the external customer. As CICs take over service provision functions that have been the exclusive domain of middlemen, the superimposition of CICs in existing service delivery channels causes conflict and frustration among channel partners, usually resulting in low cooperation. This study addresses the issue of ensuring multiple service channel cooperation by identifying the determinants of channel intermediaries' willingness to cooperate with a CIC. The results indicate that three groups of antecedents - service quality, partnership quality and image quality - lead to performance satisfaction and/or trust. Trust, in turn, directly enhances channel partners' willingness to cooperate, which finally makes it possible to leverage the potential of partnerships within service delivery systems.
\end{abstract}




\section{COOPERATING FOR SERVICE EXCELLENCE IN MULTI-CHANNEL SERVICE SYSTEMS}

\section{Introduction}

Conventionally, manufacturers in many markets have been relying almost exclusively on channel intermediaries for providing customized pre- and after-sales services. However, with rapid advances in information and communication technology, the range of service delivery options has widened considerably and extended a firm's service reach (Prabhaker, Sheehan and Coppett, 1997). Today, customers have many different alternatives in which they can interact with a company. In addition to the traditional service delivery format (faceto-face), companies are using voice-to-voice (toll-free telephone support) and bit-to-bit (online service delivery) modes, as well as combinations thereof, to deliver their services. This has enabled firms to broaden their service delivery system, achieve competitive service positioning and take the commonplace wisdom of "listening to the voice of the customer" literally (Keen, De Ruyter, Wetzels and Feinberg, 2000). The infusion of technology in the service delivery channel has considerably increased the degree of interaction (Bitner, Brown and Meuter, 2000; Dabholkar, 2000). Faced by the challenges of intelligent interactivity in pre- and post-sales services, many companies have established Customer Interaction Centers (CICs), the generic synonym for call, contact, web or assistance centers. These units serve as central hubs for customer access and are key sources for customized and remote service delivery (Anton, 2000). The customer interaction center has been defined as a "business function for blended, multi-purpose (sales, servicing and marketing) and multicommunication media (telephone, Internet, e-mail, fax, video and interactive television) that seeks to serve a variety of constituencies (customers, prospects, supply chain, distribution channel and selected employees) in a centrally consolidated setting, using both humanassisted and self-service interactions" (GartnerGroup 1998, p.2). 
Potentially, the superimposition of CICs in existing service delivery channels by manufacturers may be viewed as an inherent cause for conflict. The emergence of these interactive units poses a threat to many of the service provision functions that, until recently, have been the exclusive domain of channel intermediaries. In addition to shaking up the balance of channel power, it becomes increasingly difficult for the middlemen to use service excellence to make their product offering less substitutable and position themselves competitively in the market place. Furthermore, the risk of intermediary frustration and disillusionment is heightened by the fact that in most cases, manufacturers require their distribution network to bear the start-up and operational costs of the $\mathrm{CIC}$, even though the dealers often had no influence on the decision to set up this new, in their eyes "competitive" and centralized service function. While their dependence on the manufacturer forces channel partners such as retailers and dealers to at least a minimum of cooperation with the CIC, the willingness to cooperate may vary and considerably impede the implementation of a multichannel service strategy. As the dealers continue to play a crucial role in serving the customer and gaining a competitive edge, as well as taking care of a large part of the fulfilment process, it is imperative that they develop a positive attitude and exhibit cooperative behavior towards the CIC. Therefore, it seems relevant to obtain an in-depth insight into the determinants of channel intermediaries' willingness to cooperate with a CIC in order to leverage the potential of partnerships in service delivery systems.

Notwithstanding its significance and despite a growing number of studies on the impact of CICs on customer-firm relationships (e.g., Keen, De Ruyter, Wetzels and Feinberg, 2000; Bennington, Cummane and Conn, 2000; De Ruyter and Wetzels, 2000), the question of how to ensure issues of multiple service channel cooperation has been left virtually unanswered in the (services) marketing literature. Therefore, we aim to contribute to the literature on service channels by developing and empirically testing a model that attempts to 
explain what motivates channel intermediaries to cooperate with a CIC in delivering valueadded services to establish enduring customer-firm relationships. The paper is structured as follows. First of all, we review the literature on marketing exchange relationships in order to identify a number of key determinants of the willingness to cooperate. After constructing a conceptual framework, we subsequently report on the results of a study conducted in the automotive industry aimed at empirically testing the framework. We conclude the paper with a discussion of the theoretical and managerial implications and directions for future research.

\section{The Antecedents: Service, Partnership and Image Quality}

The crucial importance of quality has long been acknowledged in the academic as well as in the business world as a key determinant of satisfaction and trust. Although quality in and of itself is a complex subject to research, several research streams have been developed to test its effect among different constructs. Service quality has been studied extensively during the past decade, most frequently in relation to customer satisfaction (Cronin and Taylor, 1992; Iacobucci, Ostrom, Braig and Bezjian-Avery, 1996). Another stream of research has examined the role of partnership quality by exploring relationships between manufacturer and distributor, buyer and seller, customer and vendor, auditor and client, etc. (Lee and Kim, 1999). More recently, the concept of image quality has been studied in relation to satisfaction and loyalty (Andreassen and Lindestad, 1998).

Surprisingly, until now, these different types of quality have only been studied in isolation. We believe, however, that the complex relationship between CICs and traditional channel intermediaries necessitates the inclusion of service quality, partnership quality and image quality as critical antecedents of performance satisfaction and/or trust in our model. Furthermore, we propose that service quality, partnership quality and image quality are in fact higher order constructs, which consist of several dimensions. Since the literature on marketing 
exchange relationships identifies a considerable number of these dimensions, we decided to conduct a qualitative study in order to identify the key dimensions of each higher order construct relevant in the context of the CIC-channel intermediary relationship. Twenty-seven in-depth interviews were held at nine different dealership sites of a large automotive manufacturer in the Netherlands who recently set up a pan-European CIC. At each dealership, three employees who were primarily responsible for communications with the CIC - the service manager for passenger cars, the service manager for commercial vehicles and the head receptionist - were interviewed in order to get a complete overview of opinions. In general, interviews lasted between 45 minutes and 1.5 hours. On the basis of a list with discussion points, the interviews focused on how dealers perceive the service provided by the CIC, how they feel about their relationship to the new service function, and what they believe is the image of the CIC in the eyes of the external customer. As a result of this qualitative study, it became clear that for each higher order construct, three to four dimensions are of crucial importance to the dealers.

\section{Service Quality}

The raison d'être, the core of the existence of every CIC, is the provision of excellent service - to external as well as internal customers. The perception of the quality of the service encounter with the CIC has a large influence on the channel intermediary's satisfaction with the new service function. In the special context of CIC-channel intermediary relationships, four dimensions are of critical importance to service quality.

Accessibility has been defined as the time required to contact and the ease of contact of a CIC (Parasuraman, Zeithaml and Berry, 1988) and is of paramount importance in relation to voice-to-voice service delivery. A recent study of operational determinants of satisfaction with a CIC (Feinberg, Kim, Hokama, De Ruyter and Keen, 2000) even identified accessibility as the most significant determinant of satisfaction. If a customer (internal or external) has to 
wait too long before he may speak to a CIC agent, (s)he will most likely abandon the call, which of course has a very negative impact on perceived service quality (Bennington, Cummane and Conn, 2000). A second factor of importance identified in our qualitative research study is the attitude and behavior of the CIC employees. The dealer's perceptions are strongly influenced by the attitudes and behaviors of CIC agents when evaluating the quality of the service delivered (Bowen and Lawler, 1992; Burgers, De Ruyter, Keen and Streukens, 2000). This dimension is well known in the marketing literature as 'responsiveness', one of the five SERVQUAL dimensions of Parasuraman, Zeithaml and Berry (1988). They define responsiveness as "willingness to help customers and provide prompt service" (p. 23). Similarly, the interviewed dealers were also very concerned about the competence and knowhow of the CIC employees, which refers to the SERVQUAL dimension 'assurance', or the "knowledge and courtesy of employees and their ability to convey trust and confidence" (Parasuraman, Zeithaml and Berry, 1988, p. 23). Communications of responsiveness and assurance create a more personal atmosphere, which is expected to be appreciated by the dealers (Burgers, De Ruyter, Keen and Streukens, 2000). If the CIC employees convey the feeling that they are not only willing to help the dealer promptly, but that they are also competent to do so, the dealer will automatically perceive the service encounter as positive. Thus, both responsiveness and assurance are a necessary prerequisite for service quality. Finally, a special issue related to the unique relationship between a CIC and other channel intermediaries is the settlement of payments. As mentioned before, the channel intermediaries have to bear the start-up and/or operational costs of the CIC. Not only do they have to bear considerable costs, but they also are usually on the defensive side when it comes to customers having complaints about payments. If the CIC does not handle the payment properly, the dealerships are soon to hear from their customers and vice versa. Furthermore, the dealers also have to provide roadside assistance to international customers who they 
cannot bill directly. Instead, the settlement of payments will be handled by the CIC. Of course the dealers will perceive the service quality of the CIC as higher when payment issues are handled promptly and correctly. As the settlement of payment is crucial to the business success of the channel intermediary, we include it as the fourth dimension in determining service quality.

The results of our qualitative research study suggest that service quality in the context of CIC-channel intermediary relationships is made up of four dimensions: accessibility of the CIC, responsiveness and assurance of the CIC employees, and the settlement of payments handled by the CIC. All four dimensions enhance the communication process between dealers and the CIC. As Selnes (1998) has shown, this communication process is vital to the formation of satisfaction because it can result in a mutually held view regarding expectations and performance of each party. Furthermore, these dimensions contribute to a positive experience of the service encounter between dealerships and the CIC. Correspondingly, a positive service encounter leads to satisfaction with the performance of the service provider. Even though there has been a considerable debate about the causal ordering between service quality and satisfaction, we propose in line with Iacobucci, Ostrom, Braig and Bezjian-Avery (1996) and Selnes (1998) that service quality is an important antecedent of satisfaction.

$H_{1}$ : $\quad$ Service quality, consisting of accessibility, responsiveness, assurance and the settlement of payments, is positively related to the satisfaction of the channel intermediary with the performance of the CIC.

\section{Partnership Quality}

The relationship between the traditional channel intermediaries and the CIC is not limited to the service encounters described above. In order to provide maximum value to the 
external customer, the channel intermediaries and the CIC have to cooperate and coordinate their efforts - they have to form a partnership in order to best serve their customers. However, as noted by Lee and Kim (1999), partnership in itself does not guarantee a desired outcome. Instead, only high-quality partnerships evoke the wish to continue the partnership in the future and contribute to the development of trust between the partners. Therefore, it is vital to know which factors the partners, in this case the channel intermediaries and the CIC, consider to be most important when determining the quality of their partnership. In combining our literature review with the results of the qualitative study, we identify three key dimensions.

The first important dimension of partnership quality is the harmonization of conflict. Parties in a relationship will always disagree, and there will always be conflict in relational exchanges (Dwyer, Schurr and Oh, 1987). The parties involved in this study, the dealers and the CIC, have to deal with two main issues which could create conflict: (1) the dealers involuntarily have to bear at least a certain percentage of the costs of the CIC while, at the same time, depending on the CIC for certain settlements of payment, and (2) the dealers might perceive the CIC as a "competitor", as it takes over and centralizes part of the services that the dealers traditionally provided themselves in order to create customer loyalty. Conflict resolution may thus be crucial for the life of the dealer-CIC relationship, especially if the conflict is destructive, resulting in hostility and bitterness. Constructive conflict handling, on the other hand, can provide vitality and progress to the relationship. Achrol (1997, p. 59) describes harmonization of conflict as "a spirit of mutual accommodation" as agreement is sought by finding acceptable compromises instead of having to resort to formal procedures. If the CIC and the dealers engage in a dialogue and conflict is solved constructively, the respective expectations of the two parties become clear and are effectively communicated, which actually strengthens the partnership and results in trust. By displaying a willingness to 
discuss and compromise, the CIC can potentially overcome the initial resistance of the dealerships as both parties increase their understanding for each other.

The second indispensable dimension of partnership quality is the interdependence of the relationship. A firm's dependence on a partner traditionally has been defined in channels as "the firm's need to maintain a relationship with the partner to achieve its goals" (Kumar, Scheer and Steenkamp, 1995b, p. 349). Channel relationships that are asymmetric in dependence are more dysfunctional, less stable, and less trusting than symmetric relationships. The main objective of both dealers and especially the CIC is to provide excellent service to their common customers. But the success of one party is highly dependent on the performance of the other: e.g. if the CIC does not provide the necessary information to the dealer in case of a client complaint, the dealer is unlikely to be able to take the appropriate corrective action. At the same time, if the dealer refuses to solve the problem of a customer who has contacted the CIC, the CIC has little means to satisfy the expectations/needs of the customer. Kumar, Scheer and Steenkamp (1995b) found that the interdependence of a relationship is a key antecedent of trust: if the total interdependence increases, trust will increase as well. As both the dealers and the CIC face high exit barriers and receive valued contributions from each other, they have an interest in maintaining, or even strengthening their relationship, creating a "win-win" situation (Ganesan, 1994). Consequently, the interdependence of the relationship between the dealers and the CIC is a necessary condition of a long-term partnership.

A final dimension of importance to partnership quality is information exchange - the extent to which partners communicate critical or proprietary information (Downing, 1999; Lee and Kim, 1999; Morgan and Hunt, 1994). Frequent and relevant information exchanges 
demonstrate the partners' interest in the relationship and contribute to the development of trust (Lee and Kim, 1999). Information is the main "product" of a CIC and one of its main objectives is the gathering and standardization of information. As most of the interactions between the CIC and the traditional channel intermediaries concern the exchange of information, and as the performance of both ultimately depends on the quality and timeliness of this information, the inclusion of this dimension seems crucial in order to adequately describe the partnership-quality construct.

In the context of CIC-channel intermediary partnerships, three dimensions, namely harmonization of conflict, interdependence of the relationship and information exchange are crucial in determining the quality of the partnership. If a partnership displays these three dimensions, both parties show a willingness to invest a considerable amount of resources in the relationship and increase their vulnerability (e.g. through information exchange). Therefore, high quality partnerships lead to the development of trust. Without a high quality partnership between the CIC and the channel intermediaries, customer service would no doubt reflect the poor relationship between the two. As the partnership between the dealers and the CIC grows and quality is kept high, trust will also grow. Once this level of trust is reached, customers can optimally be served. We therefore propose that partnership quality is positively related to trust.

$\mathrm{H}_{2}$ : $\quad$ Partnership quality, consisting of harmonization of conflict, interdependence of the relationship and information exchange, is positively related to the channel intermediaries' trust in the CIC. 


\section{Image Quality}

Beyond impressions from the immediate service encounter and the partnership quality, the perceptions of channel intermediaries can also be influenced by the image or reputation of the CIC. Zeithaml and Bitner (1996, p. 114) define organizational image as "perceptions of an organization reflected in the associations held in customer memory". In the context of CICchannel intermediary relationships, not the image that the channel intermediaries themselves have of the CIC is of prime importance, but the image of the external customer, as this could be reflected on the channel intermediaries. Hence, the channel intermediaries might benefit from a positive image of the CIC, or conversely, be negatively affected by a negative image, as the satisfaction of the external customer with the CIC and the channel intermediaries is influenced by the CIC's image (Andreassen and Lindstad, 1998). Image quality is such an important concept because organizational images serve as a filter that has an effect on the customer's perception of the organization's operations (Zeithaml and Bitner, 1996). If a customer has a very positive image of the CIC (and the connected channel intermediaries), this will serve as a buffer against incidents of poor service. Conversely, if a customer has a very poor image of the CIC, many positive experiences will be necessary to improve this. Since there is a gap in the service marketing literature on the effect of image on customer satisfaction with CICs, and since we were dealing with a specific industry and its panEuropean $\mathrm{CIC}$, we relied heavily on the qualitative results when choosing the image dimensions. In our qualitative study, the interviewed dealers identified three dimensions of image quality which are important in the context of a pan-European CIC and which they would like to be associated with their dealerships: customer orientation, high-tech operations and international orientation. Customer orientation here is defined as the ongoing tracking and responsiveness to changing customer needs in order to deliver highquality service. If the CIC is seen as a customer intelligence unit which enables dealers to be 
more customer-oriented, the CIC contributes to the positive image of the dealerships in the eyes of the customers. High-tech operations refer to the degree of innovativeness that customers associate with the CIC and respectively with the dealers. High-tech operations are not only associated with high quality service, but also signal the existence of a competitive edge to the customers. Finally, an image of international orientation conveys the impression that both the CIC and the dealerships are speaking with "one voice" and that the high level of service provided is standardized in a large geographic area (such as Europe). If the installation of the CIC reflects such a positive image upon the dealerships, their level of satisfaction with this new service function is expected to increase. Therefore, as proposed by Andreassen and Lindestad (1998), we hypothesize a positive relationship between image quality and performance satisfaction.

$H_{3}$ : Image quality, consisting of customer orientation, high-tech operations and international orientation, is positively related to the channel intermediaries' satisfaction with the performance of the CIC.

\section{The Mediating Variables: Performance Satisfaction and Trust}

The centrality of satisfaction and trust in facilitating inter-organizational relationships is well established in the marketing exchange literature (Anderson and Narus, 1984; Dwyer, Schurr and Oh, 1987; Morgan and Hunt, 1994; Selnes, 1998, De Ruyter and Wetzels, 2000). As this article focuses on service transactions between channel intermediaries and a CIC, performance satisfaction is a critical variable. According to Wilson (1995, p. 338), channel partners must "deliver high-level satisfaction on the basic elements of the (service) transaction." As both the dealers and the CIC depend on high-quality interactions among each other in order to serve their common customers, satisfaction with the performance of the other 
party is crucial. Anderson and Narus (1984, p. 66) conceptualize satisfaction in channel relationships as a "positive affective state resulting from the appraisal of all aspects of a firm's working relationship with another firm." The use of the word "affective" in this definition underscores the fact that satisfaction is not an objective, rational assessment of the quality of performance. Instead, it is a reaction to the perceived quality of performance, which in turn results from the gap between expected and actual performance. The dealers and the CIC have clear expectations of how the other party should perform, and these expectations are best met if the other party knows about them. Oliver (1997, p. 188) emphasizes the short-term nature of performance satisfaction by conceptualizing the construct as an "immediate response to consumption".

Trust, in contrast, develops over time and is therefore viewed as a long-term relationship characteristic. Dwyer, Schurr and Oh (1987, p. 18) define trust as "the belief that a party's word or promise is reliable and that a party will fulfil its obligations in an exchange relationship." Anderson and Narus $(1984$, p. 45) complement this definition by stating that trust is "the firm's belief that another company will perform actions that will result in positive outcomes for the firm, as well as not take unexpected actions that would result in negative outcomes for the firm." Finally, Abramson and Ai (1998, p. 117) propose in line with Moorman, Zaltman and Deshpandé (1992) that trust is "the willingness to rely on another party because one has confidence in that party's credibility, competence, and reliability." As stated by De Ruyter and Wetzels (2000), trust in a CIC context can be defined as the confident belief on the part of the dealer that the CIC can be relied on to behave in such a manner that the long-term interests of the dealer will be served, and vice-versa. Furthermore, a dealer is likely to trust the CIC if he is confident that the CIC will not knowingly distort information or otherwise subvert the dealer's interest, and vice-versa (Crosby, Evans and Cowles, 1990). Selnes (1998) recognized the role of trust in reducing perceived risk. If both 
the dealers and the CIC have confidence and believe in the integrity of each other, the perceived risk associated with the relationship is reduced. If the dealers trust the CIC, they will not consider it as a "competitor" anymore. In such a way, trust plays an important role in facilitating the development and maintenance of long-term relationships.

In an attempt to establish a relationship between satisfaction and trust, Selnes (1998) proposed that trust is an aggregate evaluation at some higher level than satisfaction, and that satisfaction is in fact an important determinant of trust. Repetitive satisfactory experiences with CICs result in the dealers' belief that the new partner is able to meet expectations, and thus dealers develop trust over time. We therefore hypothesize in line with Selnes (1998) and De Ruyter and Wetzels (2000) that satisfaction is in fact an important source of trust.

H. $\quad$ Performance satisfaction of both the channel intermediaries and the CIC is positively related to the intermediary's trust in the CIC.

\section{The Key Variable: Cooperation}

While the role of cooperation has been studied extensively in an intra-organizational context (Cohen, Ledford and Spreitzer, 1996; Jones and George, 1998), only a few studies have included cooperation in channel relationships as a focal construct. Cooperation is the extent to which channel partners voluntarily undertake similar or complementary actions to achieve mutual or singular outcomes with expected reciprocation over time (Anderson and Narus, 1990). Mohr, Fisher and Nevin (1999) point out that in order to gain compliance of channel intermediaries, manufacturers could make use of power and coercion. In contrast, active cooperation, which is critical in developing a service partnership, cannot be enforced. This is also the case in the CIC-channel intermediary context. As mentioned before, most of the times, the manufacturer decides on the establishment of a CIC without soliciting the 
approval of its channel intermediaries. Due to their dependence on the manufacturer, the dealers have to accept the existence of the CIC and even bear partly the cost for its establishment and operation. But the manufacturer cannot force them to intensively use the services offered by the CIC and to engage in active cooperation. As cooperation between the CIC and the dealers is often crucial in satisfying the needs of the external customers, cooperation has to be ensured otherwise. Therefore, many researchers have made the attempt to identify constructs related to cooperation. One of the most frequently mentioned constructs in this context is trust, even though the causal ordering of the relation between trust and cooperation gives rise to considerable disagreement in the marketing exchange literature (Pruitt, 1981; Anderson and Narus, 1990; Morgan and Hunt, 1994; Weitz and Jap, 1995; Smith and Barclay, 1999). Anderson and Narus (1990), for example, expected trust to be an antecedent to cooperation, but they found the opposite relationship. In the light of this surprising result, they propose an iterative process in which respondent reports of past cooperation inform present reports of trust. Conversely, Smith and Barclay (1999), in line with Pruitt (1981) and Morgan and Hunt (1994), suggest that trust is indeed a necessary precondition for cooperation. Weitz and Jap (1995) address this uncertainty about the causal ordering and conclude that the underlying cause is the cross-sectional nature of most studies, which leads to an examination of the relationship at only one point in time. In our understanding, partners increase their vulnerability by engaging in cooperative activity, which would be unlikely to happen if they do not believe in the integrity of each other. Therefore, once trust is established, coordinated efforts will lead to outcomes that exceed what the firm would achieve if it acted only in its own best interest. In the CIC-channel intermediary context, cooperative behavior will only occur if the dealers trust the CIC and stop to consider it as a "competitor". Instead, dealers and the CIC will cooperate in order to provide service 
excellence to their common customers. Hence, we expect that trust precedes cooperation and hypothesize a positive relationship between the two constructs.

H5: Trust between the CIC and the channel intermediaries is positively related to cooperation for service excellence.

\section{The Consequence: Intention to Increase Use}

Blau (1964) suggests that cooperation signals the willingness of the partners to engage in the necessary "give and take" of a two-way relationship. As argued above, the dealers will only exhibit cooperative behavior if they trust the CIC. Once they have developed trust and are willing to cooperate, it is to be expected that they will continue and even strengthen their relationship with the CIC. In such a way, cooperation can be identified as an important driver of the intention to increase the use of the CIC in the future. One result common to many studies on the adoption of technology, such as CICs, is evidence supporting attitudes as antecedents to intentions to perform certain behaviors (Dabholkar, 1992, 1996; Davis, Bagozzi and Warshaw, 1989). The cooperation-intention to use relationship in the model implies that all else being equal, individuals form intentions to perform behaviors toward which they have a positive effect (Davis, Bagozzi and Warshaw, 1989). Close cooperation between the channel intermediaries and CICs is critical for establishing a successful long-term partnership in serving the customer. Dealers who have faith in the new service function and who actively cooperate for service excellence can be expected to have the intention to increase their use of the services of the CIC in the future. Therefore, we hypothesize a positive relationship between cooperation and the intention to increase the use of the CIC. 
$H_{6}: \quad$ Cooperation is positively related to the intention to increase the use of the services of the CIC in the future.

The complete conceptual model tested in this study is depicted in Figure 1.

\section{[PLEASE INSERT FIGURE 1 ABOUT HERE]}

\section{The Empirical Study}

\section{Research Setting}

In order to test the aforementioned hypotheses, we conducted a quantitative study in the Netherlands among the dealership sites of a large automotive manufacturer who set up a pan-European CIC - serving 11 countries - in the fall of 1998. While the start-up costs of this CIC were to the largest part accounted for by the manufacturer, the dealerships have to bear the continuous operational costs of the new service function. Before the institution of the CIC, the dealerships provided a large array of services to their customers, including their own 24hour service in case of an emergency. The dealers perceived these services to be an effective means to create customer loyalty. With the superimposition of the CIC on the existing channel network, the general customer service (information needs, complaints) as well as the 24-hour service (roadside assistance, emergencies) have been "taken away" from the dealers in order to be centralized at the pan-European CIC. Instead of handling emergencies and roadside assistance to their own customers themselves, the dealers are now "dispatched" by the CIC in order to assist all customers of the manufacturer who have a breakdown in the geographic area of the respective dealer. The resulting - often complex - payment issues are also handled via the CIC instead of directly via the dealerships. 
The quantitative study was conducted in fall 1999, exactly one year after the set up of the CIC, allowing for a reasonable time span for the surveyed dealerships to overcome initial problems and unfamiliarity with the CIC. In this way, we can be sure to have captured the true perceptions of quality, satisfaction, trust and cooperation of the dealers regarding the CIC.

\section{Data Collection}

Due to the manageable size of the Netherlands, the research population from which a selection has been made included all employees of a dealership site that could have contact with the CIC. Therefore, we contacted Managers, Customer Service Coordinators, Receptionists, and Workshop Employees throughout the Netherlands to fill out our mail survey. A mail questionnaire was chosen over other alternatives since it is one of the cheapest methods for data collection, it easily allows for a wide distribution, and it is best suited to handle complex questions. A personalized cover letter on CIC stationary and a postage-paid return envelope accompanied the questionnaires. The cover letter explained the purpose of the study and the confidentiality of the responses. A total of 732 questionnaires were sent out, of which 278 were returned. This resulted in a response rate of $37.87 \%$, which far exceeds the usual response rate of a mail questionnaire (12-18\%). After elimination of questionnaires from which excessive amounts of data were missing, the final sample consisted of 210 respondents.

Our sample varied adequately in terms of the most important background characteristics: response per vehicle sector (passenger vehicles, 20\%; commercial vehicles, $23 \%$; both, 57\%), per type of vehicle serviced (service several brands, $25 \%$; service exclusively the manufacturer's brand, 75\%) and per position of the respondent in the firm (Parts Manager, 11\%; General Manager, 13\%; Workshop Employee, 15\%; Customer Service Coordinator, 16\%; Receptionist, 18\%; Service Manager, 27\%). Only one significant 
difference was found between these six positions of respondents: the General Managers were less satisfied and disagreed more with most statements of the questionnaire than the other five groups.

\section{Measurement}

Each construct in the model is measured using a multiple-item measurement scale. All measures use a 7-point Likert type response format, with "strongly disagree" and "strongly agree" as the anchors. Some items in the questionnaire were reverse coded to detect response bias. We mainly used (sub)scales that showed internal consistency in previous research. Items were adapted to the specific characteristics of our research setting on the basis of the interviews. In addition, also on the basis of the interviews, we developed scales for five dimensions: accessibility, payment, customer orientation, high-tech operations and international orientation. The preliminary list of items developed for these subscales, consisting of five items per subscale, was subjected to reliability and exploratory factor analysis, which resulted in the elimination of four items (three for accessibility and one for payment).

A list of measurement items was developed using input from two sources: a review of the literature related to published scales measuring our constructs and the interviews conducted during our qualitative study. Service quality is measured with four subscales. Accessibility consists of two items and payment of four items that have been specifically designed for this study based on the previously conducted interviews. The measures for responsiveness (four items) and assurance (five items) are based on the SERVQUAL scale developed and extensively tested by Parasuraman, Zeithaml and Berry $(1988,1991)$. With regards to partnership quality, the interdependence of the relationship contains a selection of three items from the 6-item scale from Kumar, Scheer and Steenkamp (1995b). 
Harmonization of conflict was assessed with five items used by Anderson and Narus (1990). The 5-item scale used to measure information exchange between channel intermediaries and the CIC was recently developed by Downing (1999) in the context of information systems. Image quality consists of three subscales - customer orientation, high-tech operations and international orientation - each measured with five items specifically developed for this study. The 5-item scale for performance satisfaction is adapted from Mano and Oliver (1993). For the measurement of trust we use six items based on scales from Anderson and Narus (1990) and Kumar, Scheer, and Steenkamp (1995a). The key variable cooperation is captured by a 4-item scale, adapted from Anderson and Narus (1990). Finally, the behavioral intentions (three items) are based on a scale developed and validated by Kumar, Hibbard and Stern (1994). Appendix 1 contains sample items of the questionnaire that was used in this study.

\section{Data Analysis}

Structural equation modeling was used to test the hypothesized relationships in our model. More specifically, we performed the two-step approach as suggested by Anderson and Gerbing (1998). First, we describe the assessment of the critical measurement properties of the scales used in our study. Second, we focus on the estimation of the structural model and the testing of the specified hypothesis.

\section{Measurement properties}

We performed confirmatory factor analyses to assess the following psychometric properties of the constructs in our study: unidimensionality, reliability, convergent validity and discriminant validity (Anderson and Gerbing 1998; Bollen 1989; Steenkamp and van Trijp 1991). As the number of items adversely affects the acceptance of structural equation 
models, we split the constructs in our study into two submodels (cf. Heide and John 1990; Kumar et al. 1992). The first submodel includes the ten quality constructs, the second submodel includes satisfaction, trust, cooperation, and behavioral intentions. As the first submodel contains a large number of indicators, we followed the following strategy for assessing the psychometric properties of this submodel. First, we conducted separate analyses for each quality construct. As this first step indicated favorable properties for the individual quality constructs, we proceeded by specifying a more parsimonious model in order to estimate the three quality constructs together. The second step of our strategy consists of specifying this more parsimonious model. As the total number of indicators exceeds 30 , we specified a model in which the aggregated subscale scores act as indicators of the respective latent variables (cf. Bentler and Chou 1987; Settoon, Bennett, and Liden 1996).

The overall model fit provides the necessary and sufficient information to determine whether a set of items is unidimensional. For both submodels we obtained a good fit to the data, indicating unidimensionality. The goodness of fit statistics for the two submodels are as follows. Submodel 1: $\chi^{2}(32)=64.71 ; \mathrm{GFI}=0.90 ; \mathrm{AGFI}=0.80 ; \mathrm{TLI}=0.88 ; \mathrm{RMSEA}=0.081$. Submodel 2: $\chi^{2}(98)=156.98 ; \mathrm{GFI}=0.92 ; \mathrm{AGFI}=0.83 ; \mathrm{TLI}=0.90 ; \mathrm{RMSEA}=0.077$.

To evaluate the reliability of the constructs we used composite reliability (Jöreskog 1971). All the composite reliability values are above the recommended cut-off value of 0.60 (Nunnaly and Bernstein 1994).

Within-method convergent validity was assessed testing the significance and magnitude of each indicator's coefficient (cf. Anderson and Gerbing 1988). We found that all items loaded significantly and substantially (all loadings exceeded 0.5 ) on their respective constructs. 
Discriminant validity was evaluated by testing whether pairs of constructs were correlated less than unity. We used chi-square difference tests with one degree of freedom to test for unity between the constructs. All chi-square difference tests were significant at the $4 \%$ significance level. Inspection of the correlation matrix and the accompanying standard errors (the PHI-matrix) revealed that none of the correlations are within two standard errors of 1.0. Applying Fornell and Larcker's (1981) test of average trait variance extracted, all construct pairs demonstrate that the average variance extracted from the traits exceeds the squared correlation estimate between the respective constructs. All three tests for discriminant validity are indicative for the presence of discriminant validity.

\section{Hypothesis Testing/Results}

In order to test our hypotheses we estimated a path model with observable (manifest) variables using LISREL 8.3 (Jöreskog and Sörbom, 1989). We used LISREL to obtain maximum likelihood estimates of the path coefficients. An initial estimation of the structural model yields an acceptable fit and all hypothesized relationships are supported by the data. However, inspection of the modification indices and residuals suggests that there is still room for further improvement. More specifically, an additional path is suggested from image quality to cooperation. As this suggested additional path is justified on theoretical grounds, we decided to estimate the model with this additional path included. The respecified model yields a good fit to the data: $\chi^{2}=19.22, \mathrm{df}=11 ; \mathrm{TLI}=.90 ; \mathrm{GFI}=.96 ; \mathrm{AGFI}=.90 ; \mathrm{RMSEA}=.072$; $\mathrm{CFI}=0.99$. Furthermore, the value of the $\chi^{2} / \mathrm{df}$ ratio of 1.75 falls well within the recommended levels of 1.0 to 2.0 , which also indicates a good fit of the data to the hypothesized model.

Figure 2 gives an overview of the estimated path model. 
The significance tests for the structural model parameters are the basis for accepting or rejecting our hypotheses. A significant positive relationship between service quality and performance satisfaction supports hypothesis 1 (standardized path coefficient $=0.68$, $\mathrm{t}$ value $=10.73$ ). Service quality in this study consists of several subscales: accessibility, responsiveness, assurance and payment. If these aspects are improved, the channel intermediaries' satisfaction with the service provided will also directly increase. We also find a significant positive relationship between partnership quality and trust, which supports hypothesis 2 (standardized path coefficient $=0.39$, t-value $=2.99$ ). Constructive conflict handling, an interdependent relationship and open information exchange contribute greatly to the channel partners' trust in the new service function - the CIC. Also the relationship between the last group of antecedents, image quality, and our mediating variable performance satisfaction behaves as expected. Image quality is positively related to performance satisfaction (standardized path coefficient $=0.42$, $\mathrm{t}$-value $=6.86$ ), supporting hypothesis 3 . If channel intermediaries think that the external customer has a positive image of the CIC in terms of customer and international orientation and high-tech operations, this positive image will be associated with the channel intermediary's own business. As a result, the higher the image quality, the more satisfied the channel partner would be with the performance of the CIC. As expected, significant positive relationships are also found between performance satisfaction and trust (standardized path coefficient $=0.57$, $t$-value $=4.34$ ) and between trust and cooperation (standardized path coefficient $=0.23$, $\mathrm{t}$-value $=2.23$ ). We therefore we fail to reject hypotheses 4 and 5. In addition to partnership quality, high satisfaction of the channel intermediaries with the performance of the CIC leads in the longer term to the development of trust. In a trusting relationship, in turn, the channel partner is willing to increase its vulnerability by cooperating. Finally, as hypothesized, we found that cooperation is positively 
related to behavioral intentions (standardized path coefficient $=0.84$, $t$-value $=8.80$ ). Hence, we also fail to reject hypothesis 6 . Once the channel intermediaries are willing to cooperate, they intend to actively use the CIC in the future and to continue the relationship. The additional relationship between image quality and cooperation (standardized path coefficient $=0.69$, tvalue $=6.48$ ) can be explained by the fact that image quality is the only group of variables in our model in which the voice of the external customer is incorporated. The reason why both the CIC and the channel intermediaries exist is to serve the external customer. If the external customer is satisfied with the CIC, its positive image might convince the channel partner of the added value of the new service function and increase the willingness to cooperate.

\section{Conclusions}

Advances in technology have revolutionized service delivery in recent years. On the one hand, companies are offered a much broader range of service delivery options, while on the other hand, the degree of interaction has considerably increased (Prabhaker, Sheehan and Coppett, 1997; Dabholkar, 2000). As a result of these developments, many firms have imposed a new service function, the Customer Interaction Center (CIC), upon the existing service delivery channel, rendering the already complex relationship between manufacturers and traditional channel intermediaries even more difficult (Mohr, Fisher and Nevin, 1999). CICs are service functions with a boundary-spanning role: they are visible to both the internal as well as the external customer. As the internal customers are dependent on the manufacturer, they are forced to at least a minimum level of cooperation with the CIC. But in order to maximize the value delivered to the external customer, the CIC and the channel intermediaries have to cooperate closely.

In this paper, we attempted to identify the key factors that motivate channel intermediaries to cooperate with a CIC. We found that the CIC has to optimize its core 
services and relational efforts towards the internal customer, as well as its overall image, in order to increase satisfaction and trust, and ultimately the channel partners' willingness to cooperate. In terms of the antecedents to either performance satisfaction or trust, we identified three groups of variables: service quality, consisting of accessibility, responsiveness, assurance and settlement of payment; partnership quality, made up of harmonization of conflict, interdependence of the relationship and information exchange; and finally image quality, consisting of customer orientation, high-tech operations and international orientation.

The results from our empirical study provide support for positive relationships between service quality as well as image quality and performance satisfaction and between partnership quality and trust. These findings are in line with previous studies (Cronin and Taylor, 1992; Iacobucci, Ostrom, Braig and Bezijan-Avery, 1996; Andreassen and Lindestad, 1998; Lee and Kim, 1999). Performance satisfaction also positively relates to trust, as was already shown by Selnes (1998) and De Ruyter and Wetzels (2000). With respect to cooperation, our results provide strong support for a positive relationship between trust and cooperation (Pruitt, 1981; Morgan and Hunt, 1994; Smith and Barclay, 1999). But also one unexpected relationship emerged from our analysis of the data. We encountered a positive, direct relationship between image quality and cooperation, an observation that, at least to our knowledge, has not been previously reported in literature. This relationship probably results from the fact that image quality is the only group of variables that reflects the opinion of the external customer. If, in the eyes of the external customer, the CIC is a state-of-the-art, customer-oriented service function, it might be worthwhile for the channel intermediaries to cooperate with that new service unit. Better cooperation will improve the service provided to the external customer and improve the image of the CIC, which, in turn, will have a positive impact on the channel intermediaries' business. Finally, once the willingness to cooperate is established, we found that the channel intermediaries will have the intention to continue to 
use the CIC in the future. This positive relationship between attitude and behavioral intentions is a result common to many studies (Davis, Bagozzi and Warshaw, 1989; Dabholkar, 1992, 1996).

\section{Theoretical Implications and Future Research Guidelines}

An important contribution of our study is the simultaneous consideration of different types of quality as antecedents of satisfaction and trust. While especially service quality, but also partnership and image quality, have been studied extensively in isolation, our study proposes that the complex multi-channel environment of standardized technology-mediated service delivery necessitates a more complete conceptualization of quality. Furthermore, while the marketing exchange literature proposes numerous dimensions for each of the three quality constructs, our qualitative research study has identified a number of key dimensions for each service, partnership and image quality that play a crucial role in the context of Customer Interaction Centers.

The findings of this research should be read with the understanding that limitations exist. In the first place, our decision of which subscales to include in the groups of antecedents was based on a qualitative research study conducted in the automotive industry. As a result, other variables, which, in a different context, might play an important role in determining the willingness of channel intermediaries to cooperate with a CIC, were not considered. Future research should be directed at including other aspects of CIC-channel intermediary relationships such as empathy, reliability, commitment, communication and shared values. Secondly, the degree to which conflict exists in a CIC-channel intermediary relationship also varies according to several factors, such as the type of service provided by the new service function and whether or not the channel intermediaries have to bear any costs related to the CIC. In situations in which the CIC does not cannibalize on the existing service 
offering of the channel intermediaries and in which no costs are shifted to the channel partner, our model might have only limited applicability. Furthermore, as this empirical study was only directed at the channel intermediaries, it would be certainly worthwhile to also capture the point of view of the CIC employees and the external customer. Next, a particularly interesting result of our study is the direct positive relationship between image quality and cooperation. As this relationship has not been reported in the literature before, further research is needed to cross-validate this finding. Cultural differences might also exert influence on the results (Trompenaars and Hampden-Turner, 1998). Therefore, it is important to realize that the validity of this study limits itself to the cultural settings of the Netherlands. Future research should replicate this or a similar study in different countries to guarantee the generalizability of the results.

Furthermore, several methodological limitations exist. A second-order confirmatory factor analysis would have been more suitable in order to validate the hypothesized antecedent structure, but for this technique, a larger sample size $(n=250)$ is needed. As a result, the low factor loadings for the two subscales accessibility and payment could not be improved. Finally, all concepts and relationships were measured at one point in time, thus essentially from a static perspective. It may be worthwhile to study the CIC-channel intermediary relationship over time in order to be able to take into account the dynamics of business relationships. This consideration is especially important in this study because of the central role of trust. It is commonly known that trust only develops over time; therefore, some of the relationships examined in this study might change or intensify in the future, as the panEuropean CIC that we investigated was recently installed at the time of the study. 


\section{Managerial Implications}

The conclusions drawn from this research also hold several interesting managerial implications. Our research has pointed out and measured a number of aspects of CIC-channel intermediary relationships that should be managed in order to increase the willingness of the channel intermediaries to cooperate. From the three groups of antecedents, service quality is the one that can most easily be controlled by CICs. In terms of accessibility, a CIC has to make sure that the hold time does not exceed a pre-determined time limit and that the channel intermediaries quickly get the right person on the line. If the channel partner has to wait too long before he/she may speak to an agent or before he/she is forwarded to the right department, the channel partner will most likely abandon the call and be reluctant to voluntarily use the service of the CIC again. Similarly, to serve the channel partner right and effectively, CIC agents need to know what the channel intermediaries expect. Our research shows that two aspects of contact employee behavior are of prime importance: responsiveness and assurance. Through intensive training, CICs have to make sure that its agents are polite and helpful towards the channel partners and that they display sound technical knowledge in order to convey a feeling of confidence. Finally, we found that clear procedures have to be established to regulate payment issues, as these directly affect the financial success of the channel intermediary's business. By guaranteeing high service quality, CICs can increase the channel partners' satisfaction with its performance, which, in the long run, will lead to trust and the willingness to cooperate. Partnership quality, which directly contributes to the development of trust, can also be influenced by CICs, even though less directly than service quality. In order to ensure constructive conflict handling and open information exchange, CICs could appoint "channel partner contact employees", which are assigned to a certain number of channel partners and take care of all specific problems or issues that might arise. In such a way, the partnership between CICs and channel intermediaries does not only develop 
on the corporate, but also on a more personal level, which facilitates open communication and information exchange. Furthermore, certain procedures for the basic day-to-day information exchange should be developed, such as checklists for standard situations and the regular mailing of general information, such as newsletters. The final group of antecedents, image quality, is the only one that directly impacts the willingness of the channel intermediaries to cooperate, but it is also the most difficult to influence. Image is built on customer perceptions, and customer perceptions take time before they change. Only one of the dimensions of image quality, customer orientation, could be somewhat influenced by CICs continuously responding to customer needs. The other two dimensions, high-tech operations and international orientation, can only be indirectly affected through, for example, advertising. Even though these actions will only pay off in the long run, our study clearly indicates the importance of building a strong image.

In a time that is characterized by rapid technological advances, increasingly demanding customers and intensifying competition, new service functions, such as CICs, become indispensable for high-quality service delivery. In order to provide optimal service to the external customer, channel partners have to be willing to cooperate closely with the CIC. To enhance this willingness to cooperate, emphasis has to be placed on service quality, partnership quality and image quality, as well as performance satisfaction and trust. Only CICs that take action in order to improve their service offering to internal customers, their partnership management and their image in order to enhance the cooperation of channel partners will be able to provide service excellence to the external customer now and in the future. 


\section{References}

Abramson, N.R., and Ai, J.X.: Practising Relationship Marketing in Southeast Asia: Reducing Uncertainty and Improving Performance. Management International Review 38 (1998): 113-143.

Achrol, R.S.: Changes in the Theory of Interorganizational Relations in Marketing: Toward a Network Paradigm. Journal of the Academy of Marketing Science 25 (1997): 56-71.

Anderson, J.C. and Gerbing, D.W.: Structural Equation Modeling in Practice: A Review And Recommended Two-step Approach. Psychological Bulletin 103/1 (1988): 411-423.

Anderson, J.C., and Narus, J.A.: A Model of the Distributor's Perspective of DistributorManufacturer Working Relationships. Journal of Marketing 48 (January 1984): 62-74.

Anderson, J.C., and Narus, J.A.: A Model of Distributor Firm and Manufacturer Firm Working Partnerships. Journal of Marketing 54 (January 1990): 42-58.

Andreassen, T.W., and Lindenstad, B.: The Effect of Corporate Image in the Formation of Customer Loyalty. Journal of Service Research 1/1 (August 1998): 82-92.

Anton, J.: The Past, Present and Future of Customer Access Centers. International Journal of Service Industry Management 11/2 (2000): 120-130.

Bagozzi, R.P., and Yi, Y.: On the Evaluation of Structural Equation Models. Journal of the Academy of Marketing Science (Spring 1988): 74-94.

Bennington, L., Cummane, J., and Conn, P.: Customer Satisfaction and Call Centers: An Australian Study. International Journal of Service Industry Management 11/2 (2000): 174-184.

Bentler, P.M, and Bonett, D.G.: Significance Tests and Goodness-of-Fit in the Analysis of Covariance Structures. Psychological Bulletin 88 (1980): 588-600.

Bentler, P.M., and Chou, C.P.: Practical Issues in Structural Modeling. Sociological Methods and Research 16 (1987): 78-117. 
Bentler, P.M.: Theory and Implementation of EQS: A Structural Equations Program, BMDP Statistical Software, Los Angeles. 1985.

Bitner, M.J., Brown, S.W., and Meuter, M.L.: Technology Infusion in Service Encounters. Journal of the Academy of Marketing Science 28/1 (Winter 2000): 138-149.

Blau, P.M.: Exchange and Power in Social Life, John Wiley and Sons, New York. 1964.

Bollen, K.A.: Structural Equations with Latent Variables, John Wiley and Sons, Toronto. 1989.

Bowen, D.E. and Lawler, E.E.: The Empowerment of Service Workers: What, Why, How, and When. Sloan Management Review 33 (1992): 31-39.

Burgers, A., De Ruyter, K., Keen, C. and Streukens, S.: Customer Expectation Dimensions of Voice-to-Voice Service Encounters: A Scale-Development Study. International Journal of Service Industry Management 11/2 (2000): 142-161.

Cohen, S.G., Ledford, G.E., and Spreitzer, G.M.: A Predictive Model of Self-Managing Work Team Effectiveness. Human Relations 49 (1996): 643-676.

Cronin, Jr., J.J., and Taylor, S.A.: Measuring Service Quality: A Reexamination and Extension. Journal of Marketing 56 (1992): 55-68.

Crosby, L.A., Evans, K. and Cowles, D.: Relationship Quality in Services Selling: An Interpersonal Influence Perspective. Journal of Marketing 54 (July 1990): 68-81.

Dabholkar, P.A.: Role of Affect and Need for Interaction in On-Site Service Encounters. Advances in Consumer Research 19 (1992): 563-569.

Dabholkar, P.A.: Consumer Evaluations of New Technology-Based Self-Service Options: An Investigation of Alternative Models of Service Quality. International Journal of Research in Marketing 13 (1996): 29-51. 
Dabholkar, P.A.: Technology in Service Delivery: Implications for Self-Service and Service Support, in Handbook of Services Marketing \& Management, T.A. Swartz, and D. Iacobucci, eds., Sage Publications, Thousand Oaks. 2000, pp. 103-110.

Davis, F.D., Bagozzi, R.P., and Warshaw, P.R.: User Acceptance of Computer Technology: A Comparison of Two Theoretical Models. Management Science 35/8 (1989): 982-1003.

De Ruyter, K., and Wetzels, M.G.M.: The Impact of Perceived Listening Behavior in Voiceto-Voice Service Encounters. Journal of Service Research 2/3 (February 2000): 276-284.

Downing, C.E.: System Usage Behavior as a Proxy for User Satisfaction: An Empirical Investigation. Information \& Management 35 (1999): 203-216.

Dwyer, F.R., Schurr, P.H., and Oh, S.: Developing Buyer-Seller Relationships. Journal of Marketing 51 (April 1987): 11-27.

Feinberg, R.A., Kim, I., Hokama, L., De Ruyter, K., and Keen, C.: Operational Determinants of Caller Satisfaction in the Call Center. International Journal of Service Industry Management 11/2 (2000): 131-141.

Fornell, C. and Larcker, D.F.: Evaluating Structural Equation Models with Unobservable Variables and Measurement Error. Journal of Marketing Research 18 (February 1981): $19-50$.

Ganesan, S.: Determinants of Long-Term Orientation in Buyer-Seller Relationships. Journal of Marketing 58/2 (1994): 1-19.

GartnerGroup: Call Center Transitions, ESC10 (1998).

Gerbing, D.W., and Anderson, J.C.: The Effects of Sampling Error and Model Characteristics on Parameter Estimation for Maximum Likelihood Confirmatory Factor Analysis. Multivariate Behavioral Research 20 (1985): 255-271. 
Heide, J.B. and John, G.: Alliances in Industrial Purchasing: The Determinants of Joint Action in Buyer-Supplier Relationships. Journal of Marketing Research 27 (February 1990) 24-36.

Iaccobucci, D., Ostrom, A.L, Braig, B.M., and Bezijan-Avery, A.: A Canonical Model of Consumer Evaluations and Theoretical Bases of Expectations. Advances in Services Marketing and Management 5 (1996): 1-44.

Jones, G.R., and George, J.M.: Experience and Evolution of Trust: Implications for Cooperation and Teamwork. Academy of Management Review 23/3 (1998): 531-546.

Jöreskog, K.G.: Statistical Analysis of Sets of Congeric Tests. Psychometrika 36 (June 1971) 109-133.

Jöreskog, K.G., and Sörbom, D.: LISREL (7): A Guide to the Program and Application, Jöreskog and Sörbom/SPSS Inc., Chicago. 1989.

Keen, C., De Ruyter, K., Wetzels, M., and Feinberg, R.A.: An Empirical Analysis of Consumer Preferences Regarding Alternative Service Delivery Modes in Emerging Electronic Service Markets. Quarterly Journal of Electronic Commerce 1/1 (2000): 3147.

Kumar, N., Hibbard, J.D., and Stern, L.W.: The Nature and Consequences of Marketing Channel Intermediary Commitment. Marketing Science Institute (1994): 94-115.

Kumar, N., Scheer, L.K., and Steenkamp, J.E.M.: The Effects of Supplier Fairness on Vulnerable Resellers. Journal of Marketing Research 32 (February 1995a): 54-65.

Kumar, N., Scheer, L.K., and Steenkamp, J.E.M.: The Effects of Perceived Interdependence on Dealer Attitudes. Journal of Marketing 32 (August 1995b): 348-356.

Kumar, N., Stern, L.W., and Archol, R.S.: Assessing Reseller Performance from the perspective of the Supplier. Journal of Marketing Research 29 (May 1992): 238-253. 
Lee, J.N., and Kim, Y.G.: Effect of Partnership Quality on IS Outsourcing Success: Conceptual Framework and Empirical Validation. Journal of Management Information Systems 15/4 (Spring 1999): 29-61.

Mano, H., and Oliver, R.L.: Assessing the Dimensionality and Structure of the Consumption Experience: Evaluation, Feeling, and Satisfaction. Journal of Consumer Research 20 (December 1993): 418-430.

Mathieu, J.E.: A Cross-Level Nonrecursive Model of the Antecedents of Organizational Commitment and Satisfaction. Journal of Applied Psychology 76/5 (1991): 607-618.

Mohr, J.J., Fisher, R.J., and Nevin, J.R.: Communicating for Better Channel Relationships. Marketing Management (Summer 1999): 39-45

Moorman, C., Zaltman, G., and Deshpandé, R.: Factors Affecting Trust in Market Research Relationships. Journal of Marketing 57 (August 1992): 81-101.

Morgan, R.M., and Hunt, S.D.: The Commitment-Trust Theory of Relationship Marketing. Journal of Marketing 58 (July 1994): 20-38.

\section{Nunnaly, J.C. and I.H. Bernstein (1994) Psychometric Theory New York: McGraw Hill.}

Oliver, R.L.: Satisfaction: A Behavioral Perspective on the Consumer, McGraw-Hill, Inc., New York. 1997.

Parasuraman, A., Berry, L.L., and Zeithaml, V.A.: Refinement and Reassessment of the SERVQUAL Scale. Journal of Retailing 67 (Winter 1991): 420-450.

Parasuraman, A., Zeithaml, V.A., and Berry, L.L.: SERVQUAL: A Mulit-Item Scale for Measuring Consumer Perceptions of Service Quality. Journal of Retailing 64 (Spring 1988): 12-40.

Prahabkar, P.R., Sheehan M.J., and Coppett, J.I.: The Power of Technology in Business Selling: Call Centers. Journal of Business and Industrial Marketing 12 (1997): 222-235.

Pruitt, D.G.: Negotiation Behavior, Academic Press, Inc., New York. 1981. 
Selnes, F.: Antecedents and Consequences of Trust and Satisfaction in Buyer-Seller Relationships. European Journal of Marketing 32/3 (1998): 305-322.

Settoon, R.P., Bennett, N., and Liden, R.C.: Social Exchange in Organizations: Perceived Organizational Support, Leader-Member Exchange, and Employee Reciprocity. Journal of Applied Psychology 3/81 (1996): 219-227.

Sheppard, B.H., Hartwick, J., and Warshaw, P.R.: The Theory of Reasoned Action: A MetaAnalysis of Past Research with Recommendations for Modifications and Future Research. Journal of Consumer Research 15 (December 1988): 125-143.

Smith, J.B., and Barclay, D.W.: Selling Partner Relationships: The Role of Interdependence and Relative Influence. Journal of Personal Selling \& Sales Management 19/4 (Fall 1999): 21-40.

Steenkamp, J.B.E.M. and van Trijp, H.C.M.: The Use of LISREL in Validating Marketing Constructs. International Journal of Research in Marketing 8 (November 1991): 283299.

Trompenaars, F., and Hampden-Turner, C.: Riding the Waves of Culture, Nicholas Brealey Publishing, London. 1998.

Tucker, L.R., and Lewis, L.: The Reliability Coefficient for Maximum Likelihood Factor Analysis. Psychometrika 38 (1973): 1-10.

Weitz, B.A., and Jap, S.D.: Relationship Marketing and Distribution Channels. Journal of the Academy of Marketing Science 4/23 (1995): 305-320.

Wilson, D.T.: An Integrated Model of Buyer-Seller Relationships. Journal of the Academy of Marketing Science 23/4 (Fall 1995): 335-345.

Zeithaml, V.A., and Bitner, M.J.: Services Marketing, The McGraw-Hill Companies, Inc., New York. 1996. 
Figure 1 Conceptual Model

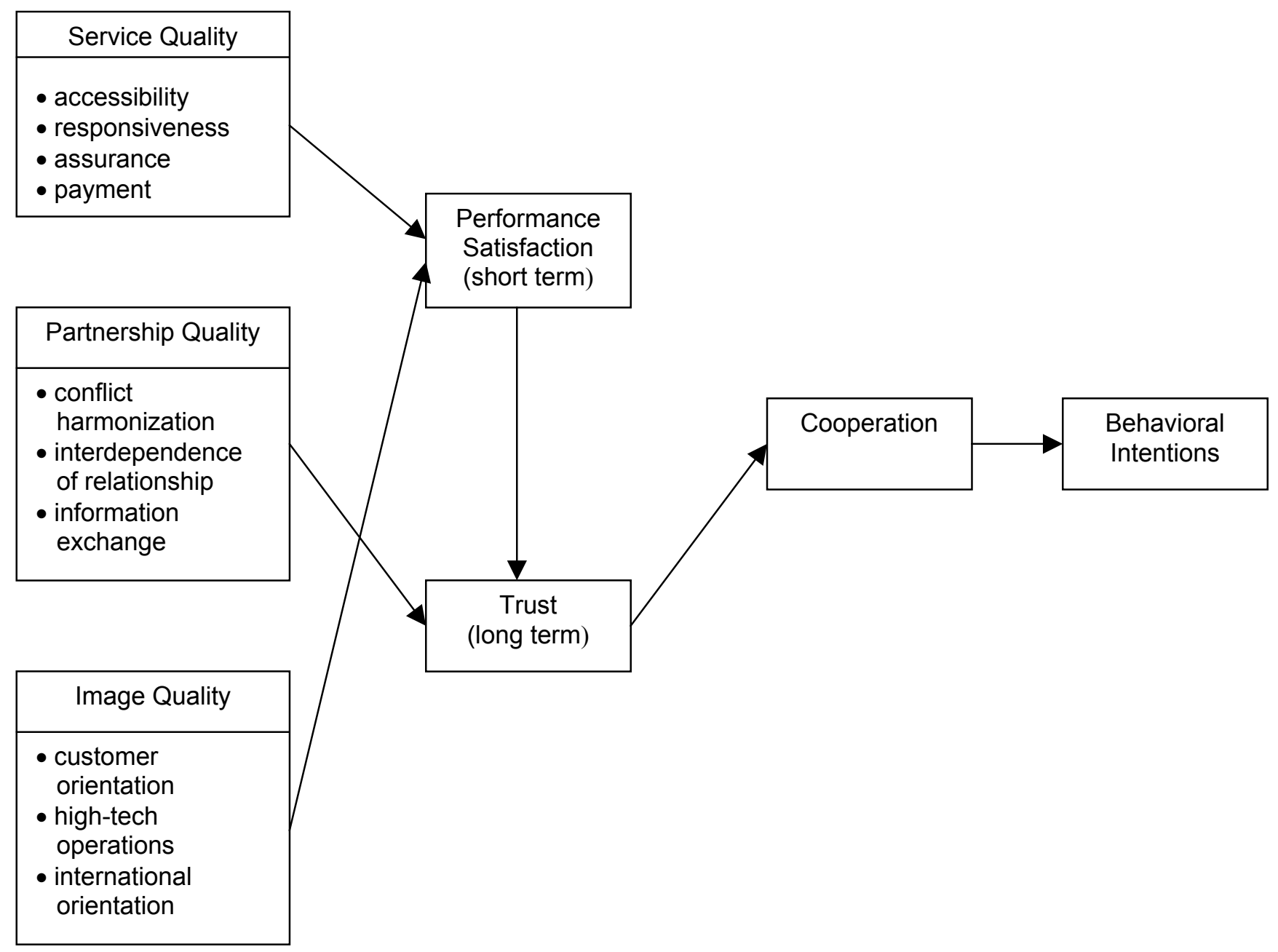


Figure 2 Path Diagram for Structural Model

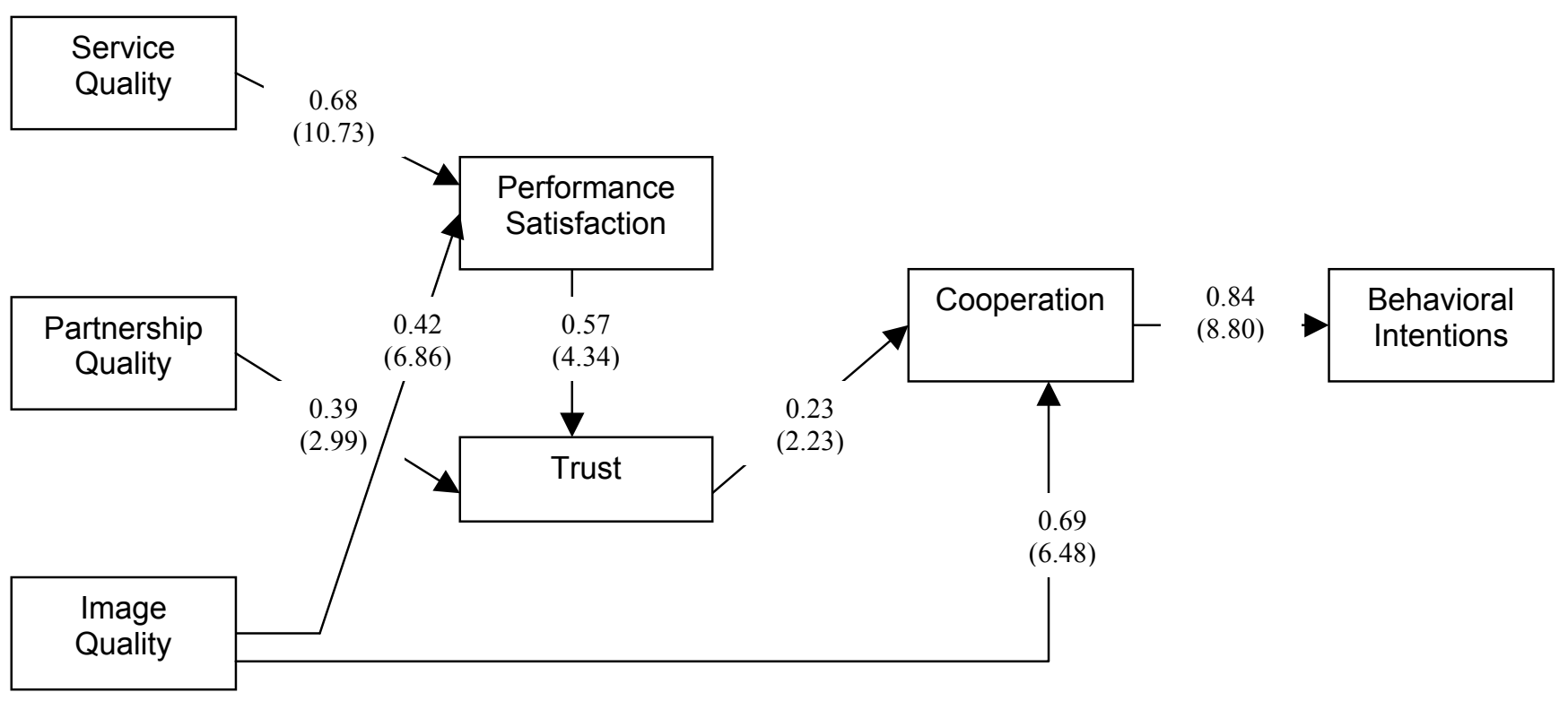


- 37 - 


\section{Appendix $1 \quad$ Sample Items from the Questionnaire}

\begin{tabular}{|c|c|}
\hline Construct & Sample Item \\
\hline \multicolumn{2}{|l|}{ Service Quality } \\
\hline Accessibility & $\begin{array}{l}\text { - The hold time when I call the CIC is not too long. } \\
\text { - I always get the right person on the line, or I am forwarded quickly to } \\
\text { the right department. }\end{array}$ \\
\hline Responsiveness & $\begin{array}{l}\text { - CIC employees are always willing to help. } \\
\text { - CIC employees always give direct answers to my questions. }\end{array}$ \\
\hline Assurance & $\begin{array}{l}\text { - CIC employees appear to be professional. } \\
\text { - The knowledge and skills of the CIC employees give me confidence. }\end{array}$ \\
\hline Payment & $\begin{array}{l}\text { - The right information is stated on the invoices. } \\
\text { - The handling of international payments has improved because of the } \\
\text { controlling function of the CIC. }\end{array}$ \\
\hline \multicolumn{2}{|l|}{ Partnership Quality } \\
\hline Conflict harmonization & $\begin{array}{l}\text { Differences of opinion between the CIC and the dealerships are } \\
\text { solved in a good manner. } \\
\text { - Preceding conflicts do not have an influence on my relationship with } \\
\text { the CIC. }\end{array}$ \\
\hline Interdependence of relationship & $\begin{array}{l}\text { - The dealerships are too dependent on the CIC for service. } \\
\text { - It would be difficult for the CIC to replace the added value that my } \\
\text { dealership provides. }\end{array}$ \\
\hline Information exchange & $\begin{array}{l}\text { - I can quickly and easily obtain the information that I need from the } \\
\text { CIC. } \\
\text { - The information that I receive from the CIC is always up-to-date. }\end{array}$ \\
\hline \multicolumn{2}{|l|}{ Image Quality } \\
\hline Customer orientation & $\begin{array}{l}\text { - The CIC allows for high-quality customer service. } \\
\text { - The CIC enables the manufacturer and the dealerships to stay close to } \\
\text { the customer. }\end{array}$ \\
\hline High technology operations & $\begin{array}{l}\text { - The CIC is an innovative way to offer better service to customers. } \\
\text { - The CIC is constantly ahead of its competitors in technological } \\
\text { innovations. }\end{array}$ \\
\hline International orientation & $\begin{array}{l}\text { - It is good that customer contacts are centrally organized for Europe. } \\
\text { - Setting up the CIC has given the manufacturer and the dealerships the } \\
\text { image of being international. }\end{array}$ \\
\hline Performance Satisfaction & $\begin{array}{l}\text { - The CIC is one of the best in the business. } \\
\text { - Overall, I am satisfied with the performance of the CIC. }\end{array}$ \\
\hline Trust & $\begin{array}{l}\text { I have faith that my customers will have a positive result when } \\
\text { dealing with the CIC. } \\
\text { The CIC considers how its decisions and actions will affect the } \\
\text { dealerships. }\end{array}$ \\
\hline Cooperation & $\begin{array}{l}\text { - The dealerships and the CIC are willing to make changes if it will } \\
\text { improve customer satisfaction. } \\
\text { - The dealerships and the CIC work as a team for the goal of overall } \\
\text { customer satisfaction. }\end{array}$ \\
\hline Behavioral Intentions & $\begin{array}{l}\text { - I inform my customers about how they can use the service of the CIC. } \\
\text { - I intend to increase my use of the CIC in the next few years. }\end{array}$ \\
\hline
\end{tabular}

